\title{
PENGARUH METODE LATIHAN TEKNIK DISTRIBUSI TERHADAP KETERAMPILAN DRIBBLING ZIG - ZAG PERMAINAN FUTSAL
}

\author{
Ekkry Siswandi \\ Universitas Bengkulu, e-mail : ekri.bengkulu14@gmail.com \\ Yarmani \\ Universitas Bengkulu \\ Santun Sihombing \\ Universitas Bengkulu \\ Defliyanto \\ Universitas Bengkulu
}

\begin{abstract}
Abstrak
Penelitian ini bertujuan untuk mengetahui pengaruh metode latihan teknik distribusi terhadap keterampilan dribbling zig - zag secara ilmiah. Dalam penelitian ini ada dua kelompok yaitu kelompok eksperimen (perlakuan) dan kontrol yang tidak diberikan perlakuan. Populasi dalam penelitian ini adalah siswa ektrakurikuler SMP Negeri 12 Kota Bengkulu pada tahun 2017. Analisis statistic yang digunakan dalam penelitian ini adalah Uji t. Adapun hasil analisis Uji t hasil perhitungan antara tes awal dan tes akhir pada kelompok eksperimen (perlakuan) terdapat pengaruh yang signitifikan. Hasil perhitungan menyatakan bahwa harga $t_{\text {hitung }}=8,95 \geq t_{\text {tabel }}=2,160$ dengan taraf $\alpha=$ 0,05, maka Ho ditolak dan Ha diterima artinya terdapat pengaruh yang signifikan antara X (Metode latihan teknik distribusi) dengan Y (Keterampilan Dribbling Zig - zag). Kontribusi metode latihan teknik distribusi terhadap keterampilan driblling zig - zag yaitu $K=r^{2} \times 100 \%=75,69 \%$. Sehingga dapat disimpulkan bahwa adanya kontribusi antara metode latihan teknik distribusi terdahap keterampilan dribbling zig -zag yaitu sebesar $75,69 \%$.
\end{abstract}

Kata Kunci : Metode Latihan, Teknik Distribusi, Dribbling Zig - Zag.

\begin{abstract}
Abstrack
This research aims to find out the influence of distrubution technique practice method toward zig - zag dribbling skill scientifically. In this research, there were 2 groups of classes. They were experimental group (treatment) and control group that received no treatment. Population of this research was extracuricular students of SMP Negeri 12 Kota Bengkulu in 2017. Statistical analysis used in this research was T test. Based on the results of $T$ test analysis, there was significant influence in calculation result beetween pre-test and post-test on experimental group. Calculation results showed that $t$ count value $=8,95 \geq t$ table $=2,160$ with $\alpha$ rate $=0,05$, so that Ho was rejected
\end{abstract}


and $\mathrm{Ha}$ was accepted. This fact showed that there was signitificant influence of $X$ (distribution technique practice metdod) toward $Y$ (zig-zag dribbling skill). Contribution of distribution technique practice method on zig - zag dribbling skill was $K=r^{2} \times 100 \%=$ $75,69 \%$. Based on the calculation results it can be concluded that there was contribution of distribution technique practice method on zig - zag dribbling skill with percentage $75,69 \%$.

Keywords : prectice method, distribution technique, zig - zag dribbling

\section{PENDAHULUAN}

Futsal merupakan satu di antara sekian banyak permainan yang di gemari oleh penduduk di seluruh belahan dunia. Ada keasyikan tersendiri yang dirasakan oleh mereka yang memainkan olahraga jenis bola besar ini. Selain mampu menciptakan suasana kebersamaan antar individu dalam satu tim, olahraga ini pun mampu menciptakan suasana kompetisi antar tim yang bertanding, Asriady Mulyono (2014:1).

Hal tersebut memberi satu kesimpulan bahwa sebetulnya futsal sendiri merupakan permainan yang saat ini sah - sah saja dimainkan baik dalam ruangan tertutup maupun terbuka, tergantung situasi dan kondisi yang ada. Dengan adanya permainan olahraga futsal, diharafkan para pemain mampu mengasah kemampuan bermain bola, terutama teknik - teknik dasar yang diekspos dengan leluasa, permainan ini juga memberikan manfaat bagi sistem ketahanan tubuh karena nyaris sepanjang permainan, seorang pemain akan berlari ke segala penjuru lapangan.

Salah satu teknik dasar yang harus dikuasai pemain futsal yaitu teknik dasar menggiring bola. Pada seorang pemain futsal, kemampuan teknik menggiring sangatlah vital. Terutama kemampuan menggiring bola seorang pemain, karena futsal sejatinya adalah permainan tim dan seorang pemain harus saling bergantung pada anggota tim untuk menciptakan permainan yang cantik dan membuat keputusan yang tepat. Jadi agar tampil baik dalam permainan seorang pemain harus dapat menggiring bola dengan baik. Menurut Justinus Lhaksana (2011 : 33) “ Menggiring bola (dribbling) merupakan keterampilan penting dan mutlak dikuasai setiap pemain futsal. Dribbling merupakan kemampuan yang dimiliki setiap pemain dalam menguasai bola sebelum diberikan kepada temannya untuk menciptakan peluang dalam mencetak gol.

Hasil observasi pengembangan olahraga futsal di SMP N 12 Kota Bengkulu untuk saat ini sangatlah baik, berdasarkan pegamatan peneliti bahwasannya minat siswa dalam mengikuti kegiataan latihan futsal baik. Tetapi dalam hal ini bahwa siswa pada saat latihan masih kurangnya memiliki keterampilan - keterampilan dalam melakukan latihan teknik dasar, terutama yakni latihan teknik menggiring bola. Padahal dalam permainan futsal menggiring bola sangatlah vital, dikarenakan apabila siswa dapat menggiring bola dengan baik akan dapat membuat permainan juga lebih baik.

Dalam beberapa bulan sebelum melakukan penelitian, peneliti melihat siswa sedang latihan dan berkomunikasi secara langsung kepada pelatih bahwasannya anak - anak cenderung sering mengalami kebosanan dalam 
bentuk latihan untuk mengasah keterampilan teknik dasar mendribbling itu sendiri dikarenakan metode atau model latihan yang belum terprogram dan jangka waktu yang singkat, sehingga membuat pelatih untuk melakukan variasi - variasi model latihan pun tidak berjalan, sehingga membuat siswa susah untuk cepat menguasai teknik dasar dalam permainan futsal yaitu menggiring bola.

Sehingga dalam hal ini untuk dapat menguasai keterampilan dribbling dengan baik seorang pemain membutuhkan latihan yang baik dan efisien. Latihan ialah upaya sadar yang dilakukan secara berkelanjutan dan sistematis untuk meningkatkan kemampuan fungsional raga yang sesuai dengan tuntutan penampilan cabang olahraga itu, untuk dapat menampilkan mutu tinggi cabang olahraga itu baik pada aspek kemampuan dasar (latihan fisik) maupun pada aspek kemampuan keterampilannya (latihan teknik).

Upaya dalam penguasaan teknik dasar haruslah menggunakan metode latihan yang baik dan efisien. Salah satu patokan yang sering digunakan untuk menggambarkan kurang meningkatnya prestasi olahraga futsal adalah kurang efisiennya suatu metode latihan dan latihan cenderung kurang menarik. Kurang teratur dan kurang menariknya suatu latihan dapat menghambat suatu penguasaan teknik dasar yang mana juga akan menghambat peningkatan suatu prestasi atlet.

\section{METODE}

Penelitian ini menggunakan design penelitian quasi eksperimental yang merupakan metode pengembangan dari true eksperimental. Design ini memiliki kelompok kontrol, tetapi tidak berfungsi sepenuhnya untuk mengontrol variabel luar yang mempengaruhi pelaksanaan eksperimen. Penelitan ini bertujuan untuk mengetahui ada tidaknya pengaruh antara variabel bebas dan variabel terikat (independent variables dan dependent variabels) (Sugiyono, 2012:77). Penelitian ini bertujuan untuk mengetahui ada tidaknya pengaruh antara variabel bebas terhadap variabel terikat Sugiyono, (2012:39). Variabel yang dimaksud dalam penelitan ini adalah metode latihan teknik distribusi (variabel bebas), sedangkan dribbling zig - zag (variabel terikat).

Dalam pengumpulan data, peneliti menyiapkan sarana dan prasarana yang dibutuhkan dalam pelaksaaan tes terlebih dahulu. Kemudian peserta didik dibariskan untuk berdoa, dan presensi. Selanjutnya peserta didik melakukan pemanasan. Setelah itu peserta didik diberi petunjuk tentang pelaksanaan tes yang akan dilaksanakan. Teknik pengumpulan data dalam penelitian ini mengunakan tes menggiring bola yang disusun oleh Arsil (2009: 129) dengan memodifikasi tekstur lapangan dan bola futsal. Data yang akan di kumpulkan dalam penelitian ini yaitu data test dribbling, melakukan tes menggiring bola sebelum sampel diberikan perlakuan/treatment dengan menggunakan metode latihan teknik distribusi.

Prinsip utama pelaksanaan tes menggiring bola utamanya adalah teste menggiring bola melewati cone sebanyak 6 buah secara zig - zag dengan jarak 1 meter, sebanyak 2 kali tes dan dalam melakukan tes sebanyak 2 kali waktu yang terbaik baik yang di pilih. Dalam hal ini Variabel yang di teliti pada penelitian kali ini adalah metode latihan teknik distribusi sebagai variabel bebas, sedangkan keterampilan menggiring bola 
(dribbling) sebagai variabel terikat. Pada penelitian kali ini peneliti menggunakan teknik pengumpulan data penelitian adalah dengan teknik tes. Pada penenlitian ini telah diketahui instrumen pengumpulan data memiliki nilai reabilitas tes sebesar $(0,61)$ dan nilai validitas tes sebesar (0,72). (Arsil, 2009 : 125).

\section{HASIL DAN PEMBAHASAN \\ Hasil}

Dari hasil pengukuran dribbling zig zag yang dilakukan pada siswa ektrakurikuler SMP Negeri 12 Kota Bengkulu pada tes awal kelompok eksperimen didapat nilai minimun: 40, nilai maksimum: 64, mean (rata-rata): 51,78, standar deviasi: 3,77. Sedangkan pada kelompok kontrol didapat nilai minimum: 40 , nilai maksimum: 64 , mean (rata - rata): 51,80, standar deviasi: 4,76.

\section{PEMBAHASAN}

Berdasarkan dari kajian teori serta perhitungan statistik dengan mengacu pada kesimpulan terhadap analisis yang dilakukan. Dalam pembahasan ini akan merujuk pada hipotesis yang diajukan dalam penelitian yaitu apakah terdapat pengaruh yang signitifikan metode latihan teknik distribusi terhadap keterampilan dribbling zig - zag permainan futsal pada siswa ektrakurikuler SMP Negeri 12 Kota Bengkulu. Apakah kelompok eksperimen yang diberikan perlakuan lebih baik dari pada kelompok kontrol yang tidak diberikan perlakuan terhadap keterampilan dribbling zig - zag pada siswa ektrakurikuler SMP Negeri 12 Kota Bengkulu.

Perhitungan t-test terhadap dribbling zig - zag sebelum dilakukan nya tes uji statistic bahwa di dapat Validitas
Setelah pemberian metode latihan teknik distribusi pada kelompok eksperimen dan pada kelompok kontrol tidak diberikan nya perlakuan metode latihan teknik distribusi, dilakukan kembali pengambilan data kedua kelompok. Pada tes akhir nilai minimum (55), nilai maksimum (74), mean (ratarata) $(64,33)$, dan standar deviasi $(4,27)$ untuk kelompok eksperimen (perlakuan) dan dapat dilihat nilai minimum (43), nilai maksimum (69), mean (rata - rata) $(56,6)$ dan standar deviasi $(6,97)$ kelompok kontrol pada tes akhir berbeda, dimana terdapat peningkatan nilai pada kelompok eksperimen yang diberikan perlakuan metode latihan teknik distribusi. Hasil uji normalitas pada kelompok eksperimen dan kontrol disajikan dalam tabel ini:

sebesar 0,72 dan Reabilitas sebesar 0,61 (Arsil,2009:125). Untuk itu dalam hal ini sebelum melakukan uji t tes maka kedua kelompok hasil tes awal di tes uji prasyarat Normalitas data tes awal sebesar 6,86 kelompok eksperimen dan 1,112 kelompok kontrol lebih kecil dari $X^{2}$ tabel sebesar 11,070 maka dapat disimpulkan bahwa data tes dribbling zig - zag berdistribusi normal, setelah itu dilakukannya uji normalitas dilakukan uji Homogenitas tes awal dan akhir terhadap keterampilan dribbling zig - zag di dapat $X^{2}$ hitung sebesar 1,932 lebih besar dari $X^{2}$ tabel sebesar 3,841, maka dapat disimpulkan bahwa data tes awal adalah homogen. Setelah dilakukan uji prasyarat maka dilakukan nya uji t dalam penelitian ini untuk melihat pengaruh dari metode latihan teknik distribusi terhadap kemampuan dribbling zig - zag. Hasil dari tes awal dan tes akhir dari kelompok 
eksperimen dimana di dapat $t_{\text {hitung }}=8,95$ $\geq t_{\text {tabel }}=2,160$. Sehingga dapat disimpulkan terdapat pengaruh yang signitifikan kelompok yang diberikan metode latihan teknik distribusi. Hasil post-test metode latihan teknik distribusi lebih tinggi dibandingkan hasil pre-test pada kelompok eksperimen.

Berdasarkan analisis diatas maka dapat disimpulkan bahwa dengan memberikan metode latihan teknik distribusi akan sangat besar pengaruhnya dalam meningkatkan keterampilan dribbling zig - zag dalam permainan futsal diperoleh uji perbedaan hasil pre-test dan post-test kelompok eksperimen sebesar 8,95 dan kontribusi metode latihan teknik distribusi terhadap keterampilan dribbling zig - zag pada permainan futsal sebesar $75,69 \%$.

Maka dari itu dalam proses penelitian ini sehingga mendapatkan hasil yang baik peneliti membagi 2 kelompok penelitian yakni kelompok eksperimen (perlakuan) dan kelompok kontrol. Pada proses penelitian kelompok eksperimen yang diberikan perlakuan lebih difokuskan untuk melihat tingkat keberhasilannya, peneliti memberikan metode latihan teknik distribusi pada kelompok eksperimen, metode ini merupakan prinsip pengaturan giliran pemberian materi latihan dilakukan melalui pengaturan waktu yang diselang seling. Sedangkan pada kelompok kontrol tidak diberikannya perlakuan sehingga dalam proses latihan kelompok kontrol hanya latihan tersendiri dengan menggunakan bola.

Dari macam latihan yang digunakan tersebut yaitu model latihan pengaturan pegulangan latihan secara berulang ulang. Dari perbedaan dua kelompok eksperimen yang di berikan perlakuan dan kelompok kontrol tidak diberikan perlakuan dapat terlihat perbedaan pengaruh yang ditimbulkan akibat dari bentuk latihan yang diberikan pada kelompok eksperimen, sehingga dapat diduga bahwa metode latihan teknik distribusi memberikan peningkatan hasil keterampilan dribbling zig -zag yang lebih baik.

Program latihan yang baik seharusnya berisikan materi teori, materi praktek, metode dan sasaran latihan yang dirinci pada setiap tahap periodesasi. Tujuan dari penyusunan program latihan adalah untuk meningkatkan kualitas keterampilan, kebugaran otot dan kebugaran energi. Faktor penguasaan dan pengembangan keterampilan teknik dasar yang sesuai dengan program latihan dapat dimiliki dengan menggunakan metode latihan yang tepat dan benar serta dijalankan dengan sunguh sungguh dalam latihan. Latihan dapat dilakukan dengan macam latihan yaitu metode latihan teknik distribusi.

\section{PENUTUP}

\section{Simpulan}

Berdasarkan hasil penelitian yang telah dilaksanakan serta dari data yang telah dihitung melalui uji prasyarat dan uji $t$, bahwa sampel berdistribusi norlam dan homogen. Hasil uji t pada penelitian ini diperoleh $t_{\text {hitung }}=8,95 \geq t_{\text {tabel }}=2,160$ sehingga dapat disimpulkan bahwa metode latihan teknik distribusi berpengaruh terhadap hasil keterampilan dribbling zig - zag pada siswa ektrakurikuler SMP Negeri 12 Kota Bengkulu.

\section{Saran}

Adapun saran - saran yang dapat di kemukakan sesuai hasil penelitian, pembahasan dan kesimpulan yang telah diuraikan di atas adalah : 
1. Bagi pelatih futsal agar dapat memberikan materi latihan yang tepat dan penyusunan program latihan khususnya untuk melatih keterampilan dasar guna meningkatkan keteramilan dribbling zig - zag permainan futsal sehingga dapat meningkatkan dan mendukung dalam kemajuan olahraga futsal.

2. Bagi siswa diharafkan semangat luar biasa yang dimiliki para siswa dapat melaksanakan program latihan hendaknya dapat diiringi dengan ketekunan dan kesungguhan supaya dapat mendapatkan hasil yang optimal sesuai apa yang diharafkan.

\section{DAFTAR PUSTAKA}

Asriady Mulyono. (2014). Buku Pintar Panduan Futsal. Jakarta Timur: Laskar Aksara.

Arsil. (2009). Evaluasi Pendidikan Jasmani dan Olahraga. Malang: Wineka Media.

Justinus Lhaksana. (2011). Taktik dan Strategi Futsal Modern. Jakarta: Be Champion (Penebar Swadaya Group).

Koni pusat.(2012).Rencana Strategis Komite Olahraga Nasional Indonesia.Jakarta

Sugiyono. (2012). Metode Penelitian Kuantitatif Kualitatif dan $R \& D$. Bandung: Alfabeta.

Tangkudung, James. (2012). Kepelatihan Olahraga Pembinaan Prestasi Olahraga. Jakarta: Cerdas jaya ,(2016).Macam-macam

Metodologi Penelitian. Jakarta: Lensa Media Pustaka Indonesia
,(2018). Sport Psychometrics

$\begin{array}{lrr}\begin{array}{l}\text { Dasar-dasar } \\ \text { Psikometri. }\end{array} & \text { Depok } & \text { instrument } \\ \text { persada } & \text { Rajagrafindo }\end{array}$

